\title{
BORN TO CONSUME? SOME ASPECTS OF CONSUMER SOCIALIZATION
}

\section{FOGYASZTÁSRA SZÜLETTÜNK? A FOGYASZTÓI SZOCIALIZÁCIÓ NÉHÁNY ASPEKTUSA}

\author{
Éva Pólya ${ }^{1}$ \\ Commerce, Marketing and International Business Department, Business Administration Faculty, John von \\ Neumann University, Hungary
}

\author{
Keywords: \\ Consumer socialization \\ Consumer behavior \\ Influencing factors \\ Family roles \\ Consumer decision making \\ Kulcsszavak: \\ Fogyasztói szocializáció \\ Fogyasztói magatartás \\ Befolyásoló tényezők \\ Családi szerepek \\ Fogyasztói döntéshozatal
}

\begin{abstract}
Are we born as consumers or we become that during our lifetime? However most of human behavior in developed societies regarded as consumer behavior, we do not born with that knowledge but we rather acquire it step by step during our life. Studying consumer socialization makes it possible to understand the most the process of becoming a consumer, the context how consumers live in the society, what are the facts that have an effect on this process.

Összefoglalás

Fogyasztónak születünk, vagy csak azzá válunk életünk során? Bár a legtöbb emberi magatartás a fejlett társadalmakban többnyire fogyasztói magatartásnak is tekinthető, ezzel a tudással nem születünk, hanem sokkal inkább lépésről lépésre sajátítjuk el életünk során ezt a tudást. A fogyasztói szocializáció tanulmányozásával érthetjük meg leginkább a fogyasztóvá válás folyamatát, azt, hogy milyen kontextusban élnek a fogyasztók a társadalomban, melyek azok a tényezők, amelyek hatást gyakorolnak erre a folyamatra.
\end{abstract}

\section{Introduction}

Study of consumer socialization became substantial after the war, this was the period when a basic need arisen to understand the background of consumer behavior, to have an overview how social trends or context, changes over different generations have an effect on that process. [18], [30] Consumer socialization is a lifelong process. Studying this process makes it possible to understand in what context consumers live in the society. [7] This is how a child acquires socially accepted behavioral norms [3] and learns to feel as it is required by the society [20], or behave according to the social norms. [9]

Consumer socialization in content refers to what children learn in connection with consumption, the process itself shows how they do that. [26] Consumer socialization is a lifelong but never a passive

\footnotetext{
1 Tel.: +36 56510300

E-mail address: polya.eva@gk.uni-neumann.hu
} 
process. [10] [30] On the contrary: children actively take part in their own socialization moreover they create their own cognition-comprehension processes instead of letting the outside world to constrain them. [18] Several researches were carried out in this topic however there are significant number of questions we have to find the answers.

\section{Consumer Socialization}

\subsection{The process of consumer socialization}

There is still a debate among scholars whether we born as consumers [22] or we became over a time [18] through consumer socialization [30]. Nevertheless it seems that root-cause embedded somehow in all children since their born [19] and children become consumers before they would learn to write, read or calculate. [15] By all means it is important to understand the process how children become consumers, their socialization to the society, because the way how a child relates to advertisements for example also found deeply his grown-up attitude. [14]

Consumer socialization starts at an early age and stems basically from the presence and being of parents and other family members. [5] An important element of this process that children purchase together with their parents and as they get older they also make purchases on their own. With the help of their parents and grandparents this can happen even by the age of 5 , by the age of 8 children become a totally independent costumer. [1] Because of its human nature mankind consume, hence can satisfy its needs. Therefore goods have to be gained, prepared our bought. In undeveloped societies, preparation of goods, in developed and consumption-oriented societies purchase with money or money-substitutes is more characteristic. People by nature simply deliver their consumer knowledge and abilities to their descendants. If in a developed society someone wants to get the necessary goods, the appropriate consumer behavior patterns must be learned. Children acquire these abilities by observation or by taking part actively in purchase decision making processes. [4]

Common purchase experiences help children to acquire all these abilities. [11] Efficient preparation of children for the consumer world of grown-ups is crucial by their consumer abilities, knowledge, behavior-orientation or attitudes. [25] This preparation function is also important because of its intermediate nature, making possible for children to try themselves in the consumer society even without the direct influence, control or supervision of their parents. [6] Interestingly childhood habits more than likely can be discovered in adulthood as well. [17]

\subsection{Children as consumers}

Consumer socialization of children helps us to understand the purchase decision making processes of family as children actively take part in them. Due to the phenomenon of inverse socialization children can also influence their parents in many cases even if they are not in a decision making role. [8]

Growing importance of children in purchase decision making processes is a result of several factors. On the one hand number of one-parent households is growing; average number of children is lower, on the other hand growing independence of children within the family have a significant role in the strengthening of this phenomenon. [16] Furthermore in the case of certain products children have a wider spectrum knowledge than their parents, hence their role in competency decisions grow. Relations within the family have also transformed: shopping is a talking point and parents are also more open and liberal. [29]

Consumer socialization is a dramatic cognitive and development process, in many cases interpreted as a several step process that describes the development stages of childhood. It is a development process in the course of what a children becomes and mature a consumer. John (1999) identified three stages of consumer socialization as it can be seen in Table 1. 
Table 1 Consumer socialization stages

\begin{tabular}{|c|c|c|c|}
\hline Characteristics & $\begin{array}{c}\text { Perceptual stage } \\
3-7 \text { years }\end{array}$ & $\begin{array}{c}\text { Analytical stage } \\
7 \text {-11 years }\end{array}$ & $\begin{array}{l}\text { Reflective stage } \\
11-16 \text { years }\end{array}$ \\
\hline \multicolumn{4}{|l|}{$\begin{array}{l}\text { Knowledge } \\
\text { structures }\end{array}$} \\
\hline Orientation & Concrete & Abstract & Abstract \\
\hline Focus & Perceptual features & $\begin{array}{l}\text { Functional/underlying } \\
\text { features }\end{array}$ & $\begin{array}{c}\text { Functional/underlying } \\
\text { features }\end{array}$ \\
\hline Complexity & $\begin{array}{l}\text { Undimensional } \\
\text { Simple }\end{array}$ & $\begin{array}{c}\text { Two or more } \\
\text { dimensions } \\
\text { Contingent ("if-then") }\end{array}$ & $\begin{array}{c}\text { Multidimensional } \\
\text { Contingent ("if-then") }\end{array}$ \\
\hline Perspective & $\begin{array}{l}\text { Egocentric (own } \\
\text { perspective) }\end{array}$ & $\begin{array}{l}\text { Dual perspectives } \\
\text { (own }+ \text { others) }\end{array}$ & $\begin{array}{l}\text { Dual perspectives in } \\
\text { social context }\end{array}$ \\
\hline \multicolumn{4}{|l|}{$\begin{array}{c}\text { Decision-making } \\
\text { and influence } \\
\text { strategies }\end{array}$} \\
\hline Orientation & Expedient & Thoughtful & Strategic \\
\hline Focus & $\begin{array}{l}\text { Perceptual features } \\
\text { Salient features }\end{array}$ & $\begin{array}{c}\text { Functional/underlying } \\
\text { features } \\
\text { Relevant features } \\
\end{array}$ & $\begin{array}{c}\text { Functional/underlying } \\
\text { features } \\
\text { Relevant features } \\
\end{array}$ \\
\hline Complexity & $\begin{array}{c}\text { Single attributes } \\
\text { Limited repertoire of } \\
\text { strategies }\end{array}$ & $\begin{array}{c}\text { Two or more } \\
\text { attributes } \\
\text { Expanded repertoire } \\
\text { of strategies }\end{array}$ & $\begin{array}{c}\text { Multiply attributes } \\
\text { Complete repertoire of } \\
\text { strategies }\end{array}$ \\
\hline Adaptivity & Emerging & Moderate & Fully developed \\
\hline Perspective & Egocentric & Dual perspectives & $\begin{array}{l}\text { Dual perspectives in } \\
\text { social context }\end{array}$ \\
\hline
\end{tabular}

Source: John, D. R. (1999): Consumer Socialization of Children. A Retrospective Look at TwentyFive Years of Research.

Perceptual features are the most stressful in perceptual stage in contrast to abstract and symbolic thoughts. Analytical stage was named after the intense development stage as children focus on things more detailed and analytical. Reflective stage refers to the phenomenon how children understand the meaning and complete social context of consumption. [13]

\subsection{Influencers of consumer socialization}

The key to understand consumer socialization is to identify the factors that can influence the process itself. [2] These have basically an environmental or a cognitive nature. [12] As to Mowen (1987) consumer socialization consist of three main components. As it can be seen on Figure 1 background factors mean environmental factors as socioeconomic status, sex, age, social class and religious background. 


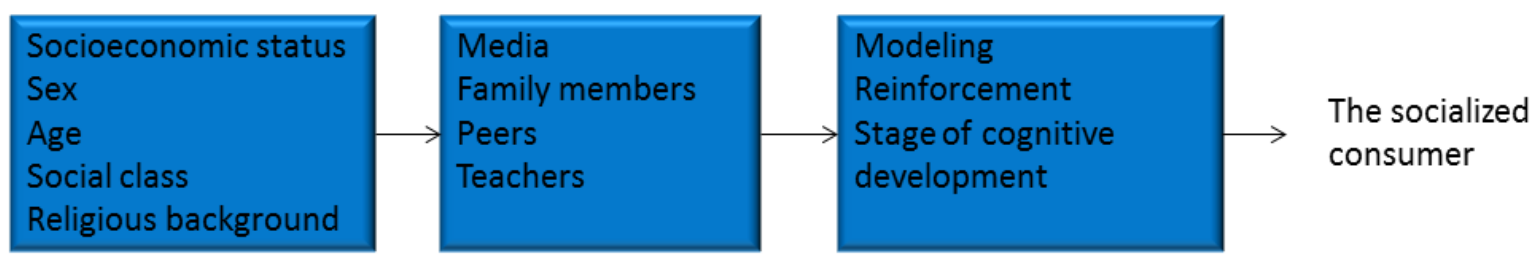

Figure 1 A model of consumer socialization Source: Mowen, J. C. (1987): Consumer behavior.

Socialization agents have a direct influence on consumers because they meet with them frequently. Parents, siblings, teachers and media belong to this group basically. Learning mechanisms refer to the process in the course of what a child gather information from the environment and store them. [21]

Family influence on consumer socialization is a result of sophisticated social interactions. This process widely depends on family communication patterns as well. Children observe their parents behavior and acquire the consumption model of the family. [26] Besides all these the existence, the age of siblings and their relationship also appear as an influencing factor in this process. [13] The parents are the ones who teach consumer habits by serving as role models, by encroaching [24] or controlling [22] children's consumption. However the financial situation of the family, the education level of parents [28], especially the employment of the mother can shade this process. [27]

Mutual influence of peers is a rudimental human feature that stems in psycho-physical and social appreciation need. During the process of consumer socialization peers have a salient role in transmitting the attitude and behavioral norms. These norms and roles later on serve as a point of reference. [10] Influential power of peers is also notable in the case of products that have a symbolic content. Peers can also support the learning process and socialization. [13] Their influence realizes in 3 different levels: a) early friendship relations with a dyadic nature, b) within smaller peer groups, who meet on a regular base, c) in a wider social space where influence is rather symbolic, than concrete or mutual. [26] Children get acquainted with products, brands, get information or try novelties as a result of their friends' influential power on their consumptions, however friends can also teach each other how to use certain products. [26]

Literature deals relatively scantly with the role of culture as a background factor which can influence consumer socialization. Present studies are usually concentrating only on one country. [13] Cross cultural studies make it possible to learn how different cultures relate to different factors such as family structures, peer relations or the influencing power of family. [13]

Out of socializing factors most of the interest still takes account of media, mass communication and the marketing activity of companies. These platforms can significantly influence the choices, product preferences or product perceptions of children. [13] Otherwise media and the influencing power of peers show many similarities. The only difference is that the latter one means a less direct measure to understand the individuals' behavior and their attitude towards social norms. [10] Anyway most of the studies concentrate on the effect of advertisements on children and usually investigate it by three (cognitive, affective, behavioral) types. Cognitive effect mostly investigates how a child can make a difference between an advertisement and a normal television show, and how much he understands the promotion purpose. The investigation of affective effect reveals that children's answer to advertisements constantly decreases approaching to concrete operational stage. In this stage children are mature enough to make a difference between advertisements and television shows. The behavioral effect refers to the process how children get influenced by advertisements and measures whether children are asking their parents to buy a particular product during family purchases. [1] 


\section{Summary}

Investigation of consumer socialization can highlight how cross-generational correspondence, changes, social trends effect the consumer behavior of young people and families. The role of children within the family is more and more came into view and that is the reason of several factors. Unequivocally they are grasping consumers and they socialize to this role at an early childhood age. During their childhood these skills, knowledge and value system are developed and these can help them to make the right decisions in the future or have an influence on them. Investigation of the three stages of consumer socialization makes it possible to get a recognition and understanding of this process in details. The key to understanding is to recognize all those factors that have either a direct or indirect effect on consumer socialization. These factors can be various, their role or significance can variate, however the investigation of influencing power of family, peers, culture and media is generally unavoidable.

\section{Acknowledgment}

This research is supported by EFOP-3.6.1-16-2016-00006 "The development and enhancement of the research potential at John von Neumann University" project. The Project is supported by the Hungarian Government and co-financed by the European Social Fund.

\section{Bibliographical References}

[1] Ali, A. - Batra, D. K. - Ravichandran, N. - Mustafa Z. - Rehman, S. U. (2012): Consumer Socialization of Children. A Conceptual Framework. In: International Journal of Scientific and Research Publications, 2 (1) pp. 1-5.

[2] Bandura, A. (1977): Social Learning Theory, Englewood Cliffs Prentice-Hall, Inc.

[3] Bilton, T. - Bonnett, K. - Jones, P. - Sheard, K. - Stanworth, M. - Webster, A. (1988): Introductory Sociology. Macmillan Press, p. 92.

[4] Carlson, L. - Grossbart, S. (1988): Parental Style and Consumer Socialization of Children. In: Journal of Consumer Research, 15 (June) pp. 77-94.

[5] Chaudhary, M. (2016): Involvement of Children in the Family Buying. A Review. In: Pacific Business Review International. 8 (11) pp. 54-62.

[6] Cram F. - Ng, S. H. (1999): Consumer Socialization. Applied psychology. An International Review. 48. pp. $297-312$.

[7] Ekström, K. M. (2006): Consumer Socialization Revisited. In: Belk R. (Ed.): Research in Consumer Behavior. Amsterdam, Elsevier Ltd. pp. 72-74.

[8] Foxall, G. R. - Goldsmith, R. E. - Brown, S. (2006): Consumer Psychology for Marketing. Oxford, International Thompson Business Press.

[9] Fromm, E. (1947). Man for himself. An inquiry into the psychology of ethics. New York, Fawcett Premier, pp. 66.

[10] Gregorio, F. - Sung Y. (2010): Understanding Attitudes Toward and Behaviors in Response to Product Placement. Journal of Advertising. 39 (1) pp. 83-96.

[11] Gunter, B. - Furnham, A. (1998): Children as Consumers. A psychological analysis of the young people's market. New York, Routledge, pp. 12-34.

[12] John, D. R. - Whitney J. C. Jr. (1986): The Development of Consumer Knowledge in Children. A Cognitive Structure Approach. In: Journal of Consumer Research 12 March, pp. 406-417.

[13] John, D. R. (1999): Consumer Socialization of Children. A Retrospective Look at Twenty-Five Years of Research. In: Journal of Consumer Research 26 December, pp. 183-213.

[14] John, D. R. (2001): 25 ans de recherche sur la socialization de l'enfant-consommateur. Recherche et Applications en Marketing, 16 (1) pp. 87-124.

[15] John, D. R. - Perrachio, L. (1993): Children as consumers. Are they „marketing” literate? In: Advances in Consumer Research, 20, pp. 373.

[16] Lehota, J. (2001): Élelmiszergazdasági marketing. Müszaki Könyvkiadó, Budapest

[17] Marshall, D. (2010): Understanding Children as Consumers. SAGE Publication Ltd., London

[18] Mazzarella, S. R. (2007): 20 question about the Youth \& the Media. New York, Peter Lang Publishing Inc. pp. 285292.

[19] McNeal, J. (2007): On Becoming a Consumer. Development of Consumer Behavior Patterns in Childhood. Burlington, Elsevier Inc. pp. 22.

[20]Moschis, G. P. (1987): Consumer socialization. A life-cycle perspective. Lexington, Lexington Press. pp. 23.

[21] Mowen, J. C. (1987): Consumer behavior. New York, Macmillan Publishing Company. pp. 413-423.

[22] Müller, M. (2001): Az áruvilág kicsi királyai. Gyerekek a reklámok világában. Budapest, Geomédia Kiadói Rt. pp. 10.

[23] Nelson, M. R. - Atkinson, L. - Rademacher, M. A. - Ahn, R. (2017): How Media and Family Build Children's Persuasion Knowledge. In: Journal of Current Issues \& Research in Advertising, pp. 1-19.

[24] North, J. N. - Kotzé T. (2001): Parents and television advertisements as consumer socialization agents for adolescents. An exploratory study. In: Journal of Family Ecology and Consumer Sciences. 29, pp.91-99. 
[25] Pólya, É. (2012): Családon belüli vásárlási döntési szerepek és folyamatok. Doktori értekezés Szent István Egyetem Gödöllő

[26] Senthilkumar, S. -Ramachandran, T. (2011): Social Networking. A Via Media for Consumer Socialization. In: Contemporary Research Issues and Challenges in Emerging Economies. pp. 339-359.

[27] Sharma, A. - Sonwaney, V. (2014): Theoretical modeling of influence of children on family purchase decision making. In: Procedia-Social and Behavioral Sciences, 2014, May, pp. 38.-46.

[28] Sharma, A. (2011): Role of Family in Consumer Socialization of Children. Literature review. In: Journal of Arts, Science\&Commerce. 2 (3) July pp. 161-167.

[29] Törőcsik, M. (2003): Fogyasztói magatartás trendek. KJK-KERSZÖV Jogi és Üzleti Kiadó Kft., Budapest

[30]Ward, S. (1974): Consumer Socialization. In: Journal of Consumer Research, 1, pp. 1-14. 